\title{
A large marine eosauropterygian reptile with affinities to nothosauroid diapsids from the Early Triassic of British Columbia, Canada
}

\author{
Torsten M. Scheyer, Andrew G. Neuman, and Donald B. Brinkman \\ Acta Palaeontologica Polonica 64 (4), 2019: 745-755 doi:https://doi.org/10.4202/app.00599.2019
}

Sauropterygia, one of the main clades of Mesozoic marine reptiles, diversified shortly after the Permo-Triassic biotic crisis and afterwards remained one of the major components of Early Triassic and later Mesozoic marine ecosystems. On the other hand, actual specimens of marine reptiles of Olenekian age are still rare in the fossil record, coming only from a few localities worldwide. Here we describe associated remains of a larger marine reptile of around $4 \mathrm{~m}$ body length, with nothosauroidean affinities from the Sulphur Mountain Formation exposed at the L cirque locality of Wapiti Lake area in British Columbia. Although the specimen records only scattered parts of the posterior vertebral column, some gastral ribs and most notably, the proximal portion of one hind limb together with a fan-shaped ischium, it represents one of the oldest records of Sauropterygia and larger representatives of aff. Nothosauroidea specifically, as well as the northernmost occurrence of such animals in the Triassic. As such, the new specimen is important for understanding the biogeography and early evolution of the group and that of Sauropterygia, in general.

Key words: Reptilia, Eosauropterygia, paleobiogeography, biotic recovery, apex predator, Olenekian, British Columbia, Ganoid Ridge.

Torsten M. Scheyer [tscheyer@pim.uzh.ch], Universität Zürich, Paläontologisches Institut und Museum, Karl Schmid-Strasse 4, CH-8006 Zürich, Switzerland. Andrew G. Neuman [Andrew.Neuman@gov.ab.ca] and Donald B. Brinkman [don.brinkman@gov.ab.ca], Royal Tyrrell Museum of Palaeontology, Box 7500, Drumheller, Alberta, T0J 0Y0, Canada.

This is an open-access article distributed under the terms of the Creative Commons Attribution License (for details please see creativecommons.org), which permits unrestricted use, distribution, and reproduction in any medium, provided the original author and source are credited. 
For f Full text (561.2 kB) ।

POF 4 Supplementary file $(2,250.1 \mathrm{kB})$ 